\title{
Dış Ticaretin İstihdam Üzerine Etkilerinin Analizi: Karabük İli Örneği (2006:1-2017:12)
}

\author{
Nihat ALTUNTEPE*
}

\section{$\ddot{O} Z$}

Gelişmekte olan ülkelerin en temel ekonomik sorunlarından biride işsizlikle mücadeledir. Ülkeler bu temel sorunu aşabilmek için farkl iktisadi politikalar üretmekte ve uygulamaktadırlar. Ülkelerin işsizlikle mücadelede uyguladıkları politikalar birbirlerinden farklı olsa bile, tek bir amac vardır o da istihdamı artırıp işsizliği azaltmaktır. Teoride dış ticaretteki gelişmelerin istihdamı artıracağı yönünde bir beklenti vardır. Yapılan bu çalışmada Karabük ilinde 2006:1-2017:12 dönemine ait diş ticaretteki gelişmelerin istihdama olan etkisi incelenmiştir. Çalı̧̧mada ekonometrik analiz Greatl programında VAR tekniği kullanılarak çözüm gerçekleştirilmiştir. Çalışmanın temel amacı; Karabük ilinde 2006:1-2017:12 dönemde ihracat ve ithalattaki değişimlerin, yine aynı dönemde istihdama olan etkisini analiz etmektir.

Anahtar Kelimeler: Istihdam, İhracat, İthalat, Granger-nedensellik testleri, Iş̧ Piyasast, Isssizlik, Dış Ticaret Dengesi, Karabük, IŞKUR.

Jel Sinıflamasi. E24, F1, C22, C32.

\section{Analysis of the Effects of Foreign Trade on Employment: Karabük Province Case (2006:1-2017:12)}

\begin{abstract}
One of the most fundamental economic problems of developing countries is unemployment. Countries are producing and implementing different economic policies in order to overcome this fundamental problem. Even if the policies that countries implement in the struggle against unemployment are different from each other, there is a single goal that is to increase employment and reduce unemployment. Dış ticaretteki gelişmelerin istihdamı artıracağı yönünde teoride bir beklenti vardir. In this study, In Karabük province, the effect of employment on foreign trade developments of 2006: 1-2017: 12 period has been examined. The econometric analysis in the study was done using the VAR technique in the Greatl program. The main aim of the study is; To analyze the effects of the changes in exports and imports in the period of 2006: 1-2017: 12 in the Karabük province, which is employment in the same period.
\end{abstract}

Key Word: Employment, Export, Import, Granger-causality tests, Labor Market, Unemployment, Employment, Export, Imports, Foreign trade balance, Karabük, IŞSUR.

Jel Clasification: E24, F1, C22, C32

\section{GİRIŞ}

Dünyadaki tüm ülkelerin gündeminde öncelikli sorun olarak yer alan işsizlik ve sonuçları; ülkelerin sosyo-ekonomik yapılarının ve gelişmişlik düzeylerinin farklı olması nedeniyle, her ülkede farklı ekonomik ve sosyal etkileriyle ortaya çıkmaktadır.

\footnotetext{
* Dr. Öğr. Üyesi, Isparta Uygulamalı Bilimler Üniversitesi, Gönen MYO-Dış Ticaret Bölümü, nihataltuntepe@isparta.edu.tr
} 
İstihdam ve işsizlik, aynı gerçeğin iki farklı fakat birbirini tamamlayan ayrılmaz parçalarıdır. İstihdam, uygulanan politikalar sonucu ulaşılmak istenen hedefi, işsizlik ise kaçınılmak istenen tarafi oluşturmaktadır. Buna bağlı olarak istihdamı artırıp, işsizliği azaltmaya yönelik politikaların uygulamaların önemini de giderek artmaktadır. İsssizlikle mücadele eden ülkemizde artan ihracata bağlı olarak dış ticaretin istihdam üzerindeki etkisinin analiz edilmesi bir zorunluluk olarak ortaya çıkmaktadır. Bu nedenle dış ticaret ve istihdamı inceleyen çeşitli çalışmalar yapılmıştır.

Bu çalışmada, öncelikle dış ticaret ve istihdam arasındaki ilişki teorik olarak ele alınacak, ilerleyen bölümlerde Karabük Ill'inde 2006 ile 2017 yılları arasındaki işgücü piyasasının görünümü ile dış ticaretteki gelişmeler ele alınacaktır. Daha sonraki bölümlerde ekonometrik bir modelleme ile diş ticaret ve istihdam değişkenleri arasındaki ilişki VAR modeli kullanılarak test edilecektir. Çalışmanın temel amacı; 2006 ile 2017 yıllarında Karabük ilinde dış ticaretteki gelişmelerin istihdama olan etkisini inceleyerek ihracat ve ithalatla istihdam arasındaki ilişkiyi tespit etmektir.

\section{TEORIKK ÇERÇEVE}

Uluslararası ticaret; pozitif iş ortamı, esnek işgücü piyasalarının oluşumunu sağlaması, yüksek kaliteli eğitim ve beceri gerektiren ve sağlayan eğitim sistemleri sayesinde dünyanın dört bir yanındaki çalışanlar, tüketiciler ve firmalar için yeni firsatlar oluşturmanın bir aracıdır. 1980'lerden bu yana; birçok gelişmekte olan ülke, ticareti artırmanın bir aracı olarak birbirleriyle yapmış oldukları ticareti daha serbest hale getirmişlerdir. Bununla birlikte, uluslararası ticaretin daha serbest hale gelmiş olmasının bir sonucu olarak istihdam oluşturup oluşturmadığ ve ücretlerde iyileşme sağlayıp sağlamadığı konusun da ciddi birtakım tartışmalar da vardır. Krugman'ın ifadesiyle; istihdam düzeyi kısa dönem toplam talebe ve uzun dönem doğal işsizlik oranına bağlı olarak, tarifelerin küçük net etkisi gibi mikro ekonomik politikalarla makroekonomik konulardır. Geleneksel olarak, daha büyük dış ticaret açığının ithalat rekabeti nedeniyle iş kayıplarına yol açabileceği tartışılmaktadır. $\mathrm{Bu}$ nedenle uluslararası ticaret sonucu istihdam oluşturma ya da işsizlik sorunu ampirik bir konu olarak tartış1maya devam etmektedir (Raj ve Sasidharan; 2015: 209-210).

Neo-klasik ticaret teorileri; karşılaştırmalı avantajları vurgulamakta ve ticaretin gelişmekte olan ülkelerde istihdamı teşvik etmede olumlu bir rol oynadığını savunmaktadırlar. Bununla birlikte, gelişmekte olan ülkelerin uygulamaları bu görüşü tamamen desteklememektedir. Aynı ülkede bu ilişkileri değerlendirirken bile farklı araştırmalar dış ticaret ile istihdam arasındaki ilişkilere farklı sonuçlara ulaşmaktadır. Gelişmiş ülkeler, vasıfsız işgücü arzının nispeten bolluğuna sahip olan gelişmekte olan ülkelerle olan ticaretleri vasıtasıyla, vasıfsız işgücüne sahip olacaklarından endişe etmektedirler. Doğu Asya ve Latin Amerika'da pek çok gelişmekte olan ülke, büyük miktarlarda imal edilen mallar üreterek ihracata yönelik stratejiyi benimsemektedirler. Hindistan, Malezya, Filipinler ve diğer Asya ülkeleri üzerine yapılan araştırmalar, ihracat sanayilerinin vasıfsız işgücü kullandığı ve ithalata rekabet eden endüstrilerin daha vasıflı 
işgücünü istihdam ettiğini ortaya koymuştur. Yine Meksika ve Brezilya gibi Latin Amerika ülkeleri hakkında yapılan diğer çalışmalar, özellikle imalat sektöründeki hızlı ihracata dayalı büyümeye rağmen, vasıfsız işgücünün istihdam edilmesiyle istihdam artışının çok yavaş veya hatta azaldığını göstermektedir. Bu nedenle, gelişmekte olan ülkelerde, imalatta karşılaştırmalı üstünlüklere sahip olsalar bile, ticaret serbestleşmesinin istihdam üzerindeki etkisi belli olmaktan uzaktır. Çin'deki ticaret ve istihdam arasındaki ilişkilere ilişkin uluslararası çalışmalar, temel olarak imalat işlerindeki değişiklikleri analiz etmekte ve dış ticaretin vasıfsız Çinli işçiler için istihdam fırsatları yarattığını ve kırsal alanlarda gizli işsizlik sorununu çözdügünü ileri sürmektedir (Xiangquan v.d., 2011:4-5).

Diğer taraftan günümüzün en tartışmalı kalkınma sorunlarından biride, küreselleşmenin dünyadaki yoksulluğu azaltmak için güçlü bir pozitif güç olup olmadığı konusunda yapılan tartışmalardır. İşgücü piyasası; küreselleşmenin yoksulluk üzerinde etkili olabileceği en temel kanaldır. Dünya ekonomisiyle artan entegrasyon, ihracat endüstrilerinde yeni işlerin yaratılması yoluyla yoksulluğu potansiyel olarak azaltabilir. Bununla birlikte dış ticaretteki büyük bir açıklık, daha önce korunan endüstriler için ithalat açısından rekabeti artırmaktadır. Bu durum bazı sektörlerde iş kayıplarına yol açabilir, işçiler işten çıkarmalar sonucunda yoksulluğa düşebilir. Küreselleşmenin iş yaratıp yaratmadığı, istihdamda kimin kazanıp kimin kaybettiği genel olarak ampirik çalışmaların konusudur. Küreselleşme ile yoksulluk arasındaki bağlantıyı anlamadaki önemine rağmen, ilk zamanlarda gelişmekte olan ülkelerde uluslararası ticaretin istihdam üzerindeki etkisi konusunda ampirik bir araştırma yapılmamıştır. Bu alandaki ilk çalışmaların çoğu, 1980'lerin başlarında çok ülkeli bir çalışma gerçekleştirilerek başlamıştır. Uluslararası ticarete bağlı olarak artan ihracat, çıktı düzeyini olumlu yönde etkilemekte, istihdamı artırmaktadır. Buna karşın daha fazla ithalat, üretimi düşürmekte ve işgücü talebini azaltmaktadır. Yine uluslararası ticaret, farklı üretim faktörlerinin üretimden alacakları payları etkilemekte, buna bağlı olarak ihracatçıların üretimini artırmakta ve ithal endüstrilerin üretimini azaltmaktadır. Yapılan ticaret endüstrilerdeki işgücü katsayılarını değiştirerek istihdam üzerinde bir etkiye sahip olabilmektedir (Sen, 2008: 3-4).

Ekonomideki geleneksel beklenti, uluslararası ticaretin serbestleştirilmesinin işgücü üzerinde iki etkiye sahip olacağıdır. Bir yandan, ithalat rekabeti ile karşı karşıya olan firmalar işlerini küçültebilir, hatta piyasadan ayrılabilir ve böylece istihdamı olumsuz etkileyebilirler. Öte yandan, yabanc1 pazara giriş yapan yeni firmaların yeni işler oluşturması nedeniyle istihdamı etkilemesi beklenir. Uluslararası ticarette en çok göz ardı edilen nokta, ihracatın istihdam yaratma etkisidir (Feenstra, Ma ve Xu , 2017).

Neoklasik modelde, ithalat sonucu ortaya çıkan rekabet, ithalat ve ihracattaki göreceli faktör yoğunluklarına bağlı olarak, işgücüne yönelik talepte serbest ticarete bağlı olarak aşağı yada yukarı yönlü bir kayma ortaya çıkarması nedeniyle istihdamı etkileyeceğidir. Serbest ticaret, çalışanlar açısından dış ticaretteki korumadan daha yüksek bir reel ücrete yol açmaktadır (Krueger,1980). 
İstihdam kavramının doğuşu ve gelişimi ücretli çalışmanın başlamasına yani yaklaşık olarak sanayi devriminin başlama yıllarına rastlamaktadır. Ancak istihdam kavramının gerçek içeriğine kavuşması ve istihdam kuramlarının gelişmesi ancak istihdamın belirgin bir sorun niteliğine dönüşmesiyle hız kazanmıştır. 1929 büyük dünya bunalımının ardından işsiz kalanlar ve bunların ekonomiye ve toplumsal yapıya yaptığı olumsuz etkileri gözlemlenmiş ve istihdam meselesi iktisat bilimi üzerinde önemle durulan bir kavram haline gelmiştir. Bu dönemde Keynes'in Genel Teorisinde istihdam meselesi üzerinde durmas1 dikkatleri bu teori üzerinde toplamıştır (Gökmen, 2007:23).

İstihdam en basit tanımı ile tüm üretim faktörlerinin etkin ve etken bir şekilde; verimli olarak kullanılması olarak ifade edilmektedir (Ören, 2011:62). İstihdam, iktisat ve sosyal siyaset dilinde ise, çalışma ve gelir sağlama kararında olan kimselerin hizmetlerinden faydalanmak üzere çalıştırılmaları anlamına gelmektedir (Seyyar, 2008:196). İstihdam, belli bir dönemde, bir ekonomide, üretim unsurlarının mevcut olan teknolojiye göre ne ölçüde değerlendirildiği biçiminde de ifade edilmektedir (Türkbal, 2005:24).

İktisadi analizlerde istihdam oranı dikkate alınmaktadır. Bundan dolayı, iş piyasası açısından emeğini arz eden ve uygun istihdam şartları içinde iş bulup, çalışanların toplamı istihdam seviyesini meydana getirirken; istihdam edilenlerin işgücü sayısına oranından istihdam oranı elde edilmektedir (Zaim, 1997:135; Köklü, 1987:67).

İşsizliğin nedenlerini ortadan kaldırmak, istihdamı artırmak üzerine birçok politika aynı anda uygulanmaktadır. İşsizlik ve istihdam sorununun çözümüne yönelik politikalar, gelir desteği yapılarak işsizliğin yol açtı̆̆1 sonuçları onarmaya yönelik önlem ve uygulamaları kapsayan pasif politikaların yanında, işsizlerin beceri ve yeteneklerini artırmaya yönelik eğitim programlarını kapsayan aktif politikalardan oluşmaktadır (Biçerli, 2004:46). Pasif iş piyasası politikaları, işsizliğin neden olduğu sosyal sorunları onarmaya ve işsizlere asgari düzeyde de olsa bir ekonomik güvence sağlamaya yönelik önlemleri içeren politikalardan oluşmaktadır (Korkmaz ve Mahiroğulları, 2007:86).

Literatürde teorik olarak, uluslararası ticaretin istihdamı nasıl etkilediğini açıklayan önemli modeller bulunmaktadır. Heckscher-Ohlin-Samuelson modeli; uluslararasi ticaretin emek talebini iki şekilde etkilediğini göstermektedir. Birincisi ölçek etkisidir. Ölçek etkisi, bir ülkede uluslararası ticaret entegrasyonu ne kadar büyükse, ihracat sektörünün çıktısı o kadar yüksek olur ki bu da emek için daha yüksek bir talep ortaya çıkardığını ifade eder. İkincisi; ikame etkisidir. İkame etksi; uluslararası ticaretteki yükselişin artan ithalat rekabeti ile çakışmasının yerli üretimin yerini almasına neden olacağını ve bu durumun ithalat sektöründe istihdamda bir düşüşe neden olacağını ortaya koymaktadır. Diğer bir model olan Greenaway'ın modeli ise; uluslararası ticaret yapmanın, ticaret yapan firmaların ticaret yapmayan diğer firmalara kıyasla daha yüksek verimlilik elde etmelerine yardımcı olabileceğini savunur. $\mathrm{Bu}$ yüksek verimlilik, firmaları işgücünü azaltmaya ve vasıfsız nitelikteki çalışanlarının işlerine son vermelerine neden olur. Teorik yaklaşımlar uluslararası ticaretle istihdam arasında bu tür bir ilişkiyi kabul 
ederken, uluslararası ticaretin istihdamda oynadığı rol ile ilgili ampirik bulgular da bunun tam tersi bir durumu ortaya koymaktadır. Gelişmekte olan ülkeler için uluslararası ticaret ve istihdam arasında pozitif bir ilişki bulunmasına rağmen, yapılan bazı ampirik çalışmalarda, örneğin Greenaway ve ark. (1999), uluslararası ticaretin istihdam üzerindeki etkisini uzun dönemli sanayi-düzey verilerini kullanıp inceleyerek, uluslararası ticaret ve istihdam arasında, endüstri-karakteristik seviyedeki kontrol değişkenleri ile negatif bir ilişki olduğunu bulmuştur. Diğer bazı çalışmalar, uluslararası ticaretin istihdam üzerinde önemli bir etkisinin olmadığını ortaya koymaktadır (Ha ve Tran, 2017: 532).

Aynı zamanda Heckscher-Ohlin modeli, emek yoğunluğuna bağlı olarak düşük ücretli çalışanların olduğu bir ülke (ör. Çin gibi) ile emek kıtllğının yaşanması nedeni ile yüksek ücretli çalışanların olduğu bir ülke (ör. Avustralya gibi) arasındaki ticaretin, faktör yoğunlukları farklı olması nedeni ile emek yoğun sektörlerin daralmasına yol açacağını göstermektedir. Bu tür ticaret, yüksek ücretli ülkelerde sermaye yoğun sektörlerin genişlemesini teşvik etse bile, emek yoğun sektörlerdeki iş kayıpları, sermaye yoğun sektörlerdeki iş kazanımlarından daha büyük olacaktır. Bu nedenle, toplam üretim istihdamı düşecektir (Tuhin, 2015: 4). Yapılan bazı çalışmalar, ticaretin istihdam üzerinde büyük bir etkiye sahip olduğunu açıkça göstermiştir. Araştırma tasarımındaki farklılıklar bir kenara konulursa, ana sonuçlar şunlardır: (i) ihracatın istihdam üzerinde büyük ve pozitif bir etkisi vardır. (ii) ithalatların istihdam üzerinde büyük ve olumsuz bir etkisi vardır. (iii) birim değer ithalat fiyat endekslerinin yüksek değerleri daha yüksek istihdama yol açmaktadır ve (iv) ticaret ve ithalat fiyatlarının istihdam üzerinde ücretlere göre daha belirgin bir etkisi vardır (Gaston, 1998: 121-122).

\section{LITERATÜR TARAMASI}

Polat ve Uslu (2010); Türkiye için; 1988:1; 2007:3 dönemini kapsayan analizlerinde, dış ticaretle istihdam arasındaki ilişkiyi kısa ve uzun dönemi dikkate alarak incelemişlerdir. Kısa dönemde, ihracat ve ithalatın istihdamı pozitif yönde etkilediğini, uzun dönemde ise ihracatın istihdamı etkilemediğini tespit etmişlerdir. Karaçor ve Saraç (2011); 1963-2009 dönemi için, dış ticaret ile sanayi sektörü istihdam oranı arasındaki ilişkiyi araştırmışlardır. Araştırma sonucunda İki değişken arasında kısa dönemde bir ilişkinin olmadığını, fakat uzun dönemde pozitif bir ilişkinin olduğunu belirlemişlerdir. Polat, Uslu ve Aydemir'in (2011) yaptıkları çalışmada Türkiye için, dış ticaretin istihdam üzerindeki etkisini 2003 2008 dönemini dikkate alarak 22 imalat sanayi sektörü için analiz etmişlerdir. Analiz sonucunda dış ticaretin istihdam üzerinde anlamlı bir etkiye sahip olmadığ sonucunu elde etmişlerdir.

Yalman (2012); Türkiye'de ticari serbestleşme ile işgücü piyasaları arasındaki nedensellik ilişkisini ortaya koymak için bir çalışma yapmıştır. Çalışmanın sonucunda Türkiye'de ticari serbestleşmenin işgücü piyasalarını negatif yönde etkilediğini tespit etmiştir.Gül ve Kamacı (2012); 1993 ve 2010 dönemini kapsayan çalışmalarında; Türkiye'nin de içinde olduğu yedi gelişmekte olan ülke ile 1980 ve 2010 dönemini kapsayan gelişmiş ülke için diş ticaretle istihdam arasındaki ilişkiyi incelemişlerdir. Yapılan analiz sonucunda gelişmiş 
ülkelerde ithalattan işsizliğe doğru nedensellik ilişkisi ortaya çıkarmışlar, ithalattan işsizliğe doğru herhangi bir ilişki bulamamışlardır. Kızılırmak (2012), Türkiye için özel imalat sanayinde dış ticaret artışının işgücü talebi üzerindeki etkisini araştırmıştır. Çalışmanın sonucunda ithalat artışı dolayısıyla ortaya çıkan rekabet artış1, firmaların işgücü kullanımındaki etkinliğini değiştirmediğini tespit etmiş̧ir. Bununla birlikte ihracat artışı olan sektörlerde ise işgücü talebinin kısa dönemde olumsuz, uzun dönemde olumlu yönde etkilendiğini ortaya koymuştur.

Akkuş (2014); 2003 - 2010 dönemi için uluslararası ticaret ve verimliliğin, Türk imalat sanayiindeki istihdama olan etkilerini incelemiştir. Yapılan analiz sonucu ihracat talebi ve ithalat rekabetinin istihdam üzerinde doğrudan etkileri anlamlı bulunmuş, ihracat talebindeki artış emek talebini pozitif yönde etkilerken, ithalat rekabetinin artması emek talebini azalttığını tespit etmiştir. Cütcü ve Cenger (2017); Türkiye için 2005:01; 2017:03 dönemini kapsayan çalışmalarında, ihracatithalat ve işsizlik arasındaki ilişkiyi incelemişler, değiş̧enler arasında uzun dönemde ilişkinin olmadığını ortaya koymuşlardır.

\section{KARABÜK İLI İŞGÜCÜ PIYASASININ GENEL GÖRÜNÜMÜ}

İşsizlikle mücadele ederken işgücü piyasasının genel görünümü bilmek ve o piyasayı tanımak piyasadaki temel sorunların çözümü için önem taşımaktadır. Çünkü işgücü piyasası doğru bir şekilde analiz edildiğinde, yerinde, zamanında ve en uygun istihdam politikalarını uygulamak mümkün olacaktır. Bu nedenlerden dolayı işsizlikle mücadele politikaları üretirken mevcut işgücü piyasasının özelliklerinin bilinmesi piyasa için doğru politikaların üretilmesi açısından önem taşımaktadır.

Tablo 1. Karabük İş Piyasasının Genel Görünümü

\begin{tabular}{|c|c|c|c|c|c|c|c|c|c|}
\hline \multirow{2}{*}{ 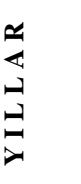 } & \multicolumn{3}{|c|}{ Yıl İçinde İşe Yerleştirme } & \multicolumn{3}{|c|}{ Kayıtlı İşgücü } & \multicolumn{3}{|c|}{ Kayıtlı İşsizler } \\
\hline & 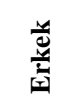 & 节 & 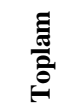 & 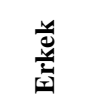 & 芯 & 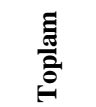 & 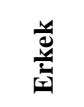 & 写 & 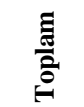 \\
\hline 2006 & 314 & 74 & 388 & 3.771 & 1.311 & 5.082 & 3.564 & 1.271 & 4.835 \\
\hline 2007 & 361 & 64 & 425 & 3637 & 893 & 4.530 & 3.163 & 866 & 4.029 \\
\hline 2008 & 330 & 28 & 358 & 6.776 & 2.021 & 9.197 & 5.988 & 2.331 & 8.319 \\
\hline 2009 & 348 & 28 & 376 & 6776 & 2.421 & 9.197 & 5.988 & 2.331 & 8.319 \\
\hline 2010 & 744 & 55 & 799 & 5.915 & 2.365 & 8.280 & 4.978 & 2.247 & 7.225 \\
\hline 2011 & 1.237 & 283 & 1.520 & 5.572 & 3.897 & 9.469 & 4.425 & 3.610 & 8.035 \\
\hline 2012 & 977 & 599 & 1.576 & 8.603 & 6.276 & 14.879 & 4.767 & 4.141 & 8.908 \\
\hline 2013 & 2.168 & 1.088 & 3.256 & 10.634 & 8.212 & 18.846 & 4.908 & 4.694 & 9.602 \\
\hline 2014 & 2.448 & 965 & 3.413 & 10.866 & 9.056 & 19.922 & 4.709 & 5.494 & 10.203 \\
\hline 2015 & 2.850 & 986 & 3.836 & 12.652 & 9.916 & 22.568 & 3.826 & 4.419 & 8.245 \\
\hline 2016 & 3.702 & 1.256 & 4.958 & 7.528 & 6.698 & 14.226 & 3.826 & 5.442 & 9.894 \\
\hline 2017 & 5.656 & 4.143 & 9.799 & 9.833 & 9.246 & 19.079 & 4.177 & 5.103 & 9.280 \\
\hline
\end{tabular}

Kaynak: IŞKUR Yillık Raporlar. 
Tablo 1'de Karabük ilinin 2006 ve 2017 yıllarına ait iş piyasası verileri görülmektedir. Bu verilere göre; Karabük'te 2006 yılında 388 kişi işe yerleştirilmiş iken bu sayısı 2017 yılında 9.799 kişiye yükselmiştir. Buna bağlı olarak 2007 yılında 4.835 kişi olan kayıtlı işsiz sayısı, 2017 yılında 9.280 kişiye yükselmiştir. Kayıtlı işgücüne bakıldığında ise; 2006 yılında bu rakam 5.082 iken 2017 yılında 19.079 kişiye yükselmiştir. Tablo bir bütün olarak incelendiğinde, adı geçen yıllarda Karabük'te kayıtlı işgücü sayısı ve işe yerleştirmeler artış gösterirken, kayıtlı işsizlerin sayısı da azalmıştır. 2015 yılı hem yıl içinde işe yerleştirmelerin hem de kayıtlı işgücünün en çok olduğu yıl olarak göze çarparken, 2014 yılı da kayıtlı işsizlerin en çok olduğu yıl olarak dikkati çekmektedir.

\section{KARABÜK İLİ DIŞ TİCARETTEKİ GELISŞIM}

Dış ticaret ihracat ve ithalattan oluşmaktadır. Dış ticaret; istihdamı ekonomik büyümeyi etkilemesi açısından ekonomiler için önem taşır. Dış ticaretin en önemli göstergeleri diş ticaret hacmi ve diş ticaret dengesidir. Diş ticaret hacmi ithalat ve ihracat toplamından oluşurken, diş ticaret dengesi ihracat ve ithalat arasındaki farktan oluşur. Karabük ilinde dış ticaret hacmi ve dış ticaret dengesindeki gelişmeler aşağıdaki tablo 2'de ele alınmıştır.

Tablo 2. Karabük İli Dış Ticaret Dengesi (2006-2017) (Bin \$)

\begin{tabular}{|r|c|c|c|c|}
\hline Yıllar & İhracat & İthalat & Diş Ticaret Hacmi & Dış Ticaret Dengesi \\
\hline $\mathbf{2 0 0 6}$ & 13915 & 189361 & 203276 & -175447 \\
\hline $\mathbf{2 0 0 7}$ & 17567 & 143695 & 161262 & -126128 \\
\hline $\mathbf{2 0 0 8}$ & 30299 & 270110 & 300409 & -239810 \\
\hline $\mathbf{2 0 0 9}$ & 58064 & 214035 & 272100 & -155971 \\
\hline $\mathbf{2 0 1 0}$ & 139790 & 319191 & 458981 & - \\
\hline $\mathbf{2 0 1 1}$ & 224020 & 417982 & 642002 & - \\
\hline $\mathbf{2 0 1 2}$ & 167424 & 482827 & 650252 & -3193962 \\
\hline $\mathbf{2 0 1 3}$ & 258722 & 492643 & 751365 & -233922 \\
\hline $\mathbf{2 0 1 4}$ & 296651 & 551628 & 848279 & -254978 \\
\hline $\mathbf{2 0 1 5}$ & 214945 & 520438 & 735382 & -305493 \\
\hline $\mathbf{2 0 1 6}$ & 245163 & 456295 & 701458 & -211133 \\
\hline $\mathbf{2 0 1 7}$ & 326129 & 721194 & 1047323 & -395066 \\
\hline
\end{tabular}

Kaynak: TUIK.

Tablo 2'de Karabük ilinin 2006 ile 2017 yılları arasında dış ticaretindeki gelişmeler gösterilmiştir. İlde 2006 yllında ihracat 13.915 bin dolar iken, 2017 y1lında 326.129 bin dolara yükselmiştir. Yine ilde ithalat 2006 y1lında 189.361 bin dolar iken, 2017 yılında 721.194 bin dolara yükselmiştir. Dış ticaret hacmi 2006 yılında 203.276 bin dolar iken, 2017 yılında 1.047.232 bin dolara yükselmiştir. Dış ticaret açığ 2006 yılında 175.447 bin dolar iken, 2017 yılında 395.066 bin dolara yükselmiştir. 


\section{METODOLOJI}

Çalışmada, istihdam (EMP), ihracat (EXP) ve ithalat (IMP) olmak üzere üç tane değişken kullanılmıştır. Bu değişkenlere ait veriler, 2006 yılı temel alınarak 2017 yılına kadar aylık hazırlanmıştır. Analizde en iyi modelin seçilebilmesi için grafik çizimleri ve her bir model için $\mathrm{R}^{2}$ değerlerinin sonuçlarına göre değişkenlerin logaritmaları alınarak çözüm gerçekleştirilmiştir. Gretl programında mevsimsellikten arındırılan ve logaritmaları alınan değişkenlerin durağanlık testi yapılmış, eşbütünleşme analizi, gecikme uzunluğu testi, VAR çözümü, etki-tepki analizi, varyans ayrıştırması yapılmıştır. Yine modelin birim çembere göre var ters kökleri çözümü gretl programında gerçekleştirilmiştir.

Özellikle iktisadi değişkenler arasındaki ilişki incelenirken, bütünlügün sağlanması için kurulan modele ve içsel ve dışsal değişken ayrımının doğru yapılmasına özen gösterilmelidir. VAR tekniğinde, modelin kurulması aşamasında modeli kısıtlayan çeşitli varsayımların kullanılması gerekmemektedir. VAR tekniği kullanılan değişkenleri bir sistem bütünlüğü içinde ele aldığından ve kesinlikle içsel ve dışsal değişken ayrımına gerek olmadığından, iktisadi teorinin öne sürdüğü kısıtlamaların, varsayımların, model tanımını bozmadığı belirtilmiştir (Özgen ve Güloğlu, 2004: 95).

Analiz yapılırken Türkiye İhracatçılar Meclisi, Türkiye Cumhuriyet Merkez Bankası, Türkiye İstatistik Kurumu, İşKUR ve Kalkınma Bakanlığı verilerinden faydalanılmıştır. Yapılan bu çalışmada; 2006-2017 yılları arasında Karabük ilinde ihracat, ithalat ve istihdam verileri aylık değerler olarak modele dâhil edilmiştir. Yapılan analizde öncelikle hangi ekonometrik modelin kullanılması gerektiği, modelde yer alan değişkenlerin grafikleri ve $\mathrm{R}^{2}$ ’lerine bakılarak tespit edilmiştir. Model belirlemek için yapılan analizde logaritmik fonksiyon modelinin en uygun model olduğu ortaya çıkmıştır.

\section{VERI SETI}

Model çözümünde kullanılan veriler; Karabük ilini kapsayan 2006 ile 2017 y1llarına ait aylık verilerdir. Veriler 2006:1-2017:12 dönemlerini kapsamaktadır. Veri seti, Türkiye İstatistik Kurumu (TÜIK), Türkiye İhracatçılar Meclisi (TİM) ve İSKUR'un veri tabanlarından derlenmiştir. Değişkenler; Karabük iline ait istihdam (EMP), ihracat (EXP) ve ithalat (IMP) değerlerinden oluşmaktadır. Değişkenlerden EXP ve IMP değişkenleri dolar cinsinden ele alınarak ekonometrik analize tabi tutulmuşlardır.

Tablo 3. Modeldeki Değiş̧kenler ve Değişkenlerin Tanımı

\begin{tabular}{|c|c|}
\hline Değişkenler & \multicolumn{1}{|c|}{ Tanımı } \\
\hline EMP & Karabük İli İstihdamı \\
\hline EXP & Karabük İli İhracatı \\
\hline IMP & Karabük İli İthalatı \\
\hline
\end{tabular}




\section{MODELIN VAR ÇÖZÜMÜ}

\section{A. ADF Birim-Kök Testi}

Tablo 4. ADF Birim-Kök Testi Sonuçları

\begin{tabular}{|c|c|c|c|}
\hline \multirow{4}{*}{ Düzey } & Değişkenler & Sabit Terim & Sabit Terim ve Trend \\
\hline \multirow{7}{*}{ I.Farkları } & EMP & $\begin{array}{c}(-3,83492) \\
0,002581\end{array}$ & $\begin{array}{c}(-3,76633) \\
0,01825\end{array}$ \\
\cline { 2 - 4 } & \multirow{2}{*}{ EXP } & $\begin{array}{c}(-1,6777) \\
0,4427\end{array}$ & $\begin{array}{c}(-1,64239) \\
0,7763\end{array}$ \\
\cline { 2 - 4 } & \multirow{2}{*}{ IMP } & $(-4,63126)$ & $(-5,95221)$ \\
& EMP & 0,0001 & $1,515 \mathrm{e}-006$ \\
\hline & \multirow{2}{*}{ EXP } & - & - \\
\cline { 2 - 4 } & IMP & $(-6,05227)$ & $(-6,04325)$ \\
& & - & $9,093 \mathrm{e}-007$ \\
\hline
\end{tabular}

Tablo 4'de modele dahil edilmiş olan değişkenler için ADF Birim-Kök Testi sonuçları görülmektedir. ADF Birim-Kök Testinde gecikme uzunluğu 12 olarak seçilmiştir. Yapılan test sonuçlarına göre; EMP ve IMP değişkenleri düzey seviyesinde durağandır. Düzey seviyesinde durağan olmayan EXP değişkenin I. farkı alınarak ADF birim-kök testi uygulanmıştır. Analiz sonucu EXP değişkeninin I. Farkının durağan olduğu görülmüsstür.

\section{B. Gecikme Uzunluğunun Belirlenmesi}

Aşağıdaki yıldız imleri, bağlı oldukları bilgi ölçütüne ait en iyi (yani en az olan) değerleri göstermektedir. AIC $=$ Akaike bilgi ölçütü, $\mathrm{BIC}=$ Schwarz Bayesçi ölçüt, HQC = Hannan-Quinn ölçütü.

Tablo 5. Gecikme Uzunluğu Testi Sonuçları

\begin{tabular}{|c|l|l|c|c|c|}
\hline gecik & log-olb & $\mathbf{p}(\mathbf{O O})$ & AIC & BIC & HQC \\
\hline $\mathbf{1}$ & $-432,68755$ & & 7,473740 & $7,753988^{*}$ & $7,587540^{*}$ \\
\hline $\mathbf{2}$ & $-425,57702$ & 0,11468 & 7,505496 & 7,995930 & 7,704646 \\
\hline $\mathbf{3}$ & $-410,03868$ & 0,00029 & 7,395608 & 8,096227 & 7,680107 \\
\hline $\mathbf{4}$ & $-400,73422$ & 0,02873 & 7,390491 & 8,301296 & 7,760340 \\
\hline $\mathbf{5}$ & $-390,95685$ & 0,02087 & 7,377426 & 8,498417 & 7,832625 \\
\hline $\mathbf{6}$ & $-384,58603$ & 0,17465 & 7,421614 & 8,752791 & 7,962163 \\
\hline $\mathbf{7}$ & $-376,30720$ & 0,05611 & 7,433734 & 8,975097 & 8,059633 \\
\hline $\mathbf{8}$ & $-366,88964$ & 0,02663 & 7,426717 & 9,178265 & 8,137965 \\
\hline $\mathbf{9}$ & $-348,47445$ & 0,00003 & 7,268478 & 9,230212 & 8,065077 \\
\hline $\mathbf{1 0}$ & $-338,71569$ & 0,02113 & 7,255726 & 9,427646 & 8,137674 \\
\hline $\mathbf{1 1}$ & $-325,74932$ & 0,00210 & 7,189064 & 9,571170 & 8,156362 \\
\hline $\mathbf{1 2}$ & $-300,90675$ & 0,00000 & $\mathbf{6 , 9 2 2 8 0 3}$ & 9,515094 & 7,975450 \\
\hline
\end{tabular}

Tablo 5'de VAR modeli için Gretl ortamında çözülen gecikme uzunluğunun belirlenmesi testi yer almaktadır. Yapılan test sonucunda en iyi (AIC'ye göre) değerleri gösterdiğinden dolayı gecikme uzunluğu olarak 12 seçilmiştir.

\section{Eşbütünleşme Testi}

Tablo 6. Eşbütünleşme Test Sonuçları OLS

Model 1: SEK (OLS), kullanılan gözlemler: 2007:02-2017:12 (T = 131)Bağımlı değişken: 1_EMP

\begin{tabular}{|l|c|c|c|c|c|}
\hline & Katsayı & Ölç. Hata & t-oranı & $p$-değeri & \\
\hline Const & 4,66298 & 0,111398 & 41,86 & $<0,0001$ & *** \\
\hline d_sd_1_EXP & 0,0616660 & 0,113344 & 0,5441 & 0,5873 & \\
\hline sd_1_IMP & $-0,0473830$ & 0,179700 & $-0,2637$ & 0,7925 & \\
\hline
\end{tabular}


Nihat Altuntepe / Dış Ticaretin İstihdam Üzerine Etkilerinin Analizi: Karabük İli Örneği (2006:1-2017:12)

\begin{tabular}{|l|r|l|l|r|}
\hline Bağımlı değişken ort & 4,658789 & Bağımlı değişken ö.s. & 1,253752 \\
\hline Kalıntı kareleri top & 203,6306 & Bağlanım ö.h. & 1,261295 \\
\hline R-kare & 0,003502 & Ayarlamalı R-kare & $-0,012068$ \\
\hline F(2, 128) & 0,224904 & P-değeri(F) & 0,798908 \\
\hline Log-olabilirlik & $-214,7737$ & Akaike ölçütü & 435,5473 \\
\hline Schwarz ölçütü & 444,1729 & & Hannan-Quinn & 439,0523 \\
\hline Ro & 0,695139 & & Durbin-Watson & 0,585164 \\
\hline
\end{tabular}

\begin{tabular}{|c|l|l|l|r|}
\hline \multirow{2}{*}{ Değişkenler } & \multicolumn{2}{|c|}{ Sabit Terim } & \multicolumn{2}{c|}{ Sabit terim ve Trend } \\
\cline { 2 - 5 } & Sınama istatistiği & p-değeri & Sınama istatistiği & p-değeri \\
\hline \multirow{2}{*}{ EMP } & $-0,98445$ & 0,761 & $-9,16181$ & $3,932 \mathrm{e}-012$ \\
\hline
\end{tabular}

Modelde yer alan değişkenler arasında bir eşbütünleşim ilişkisinin test sonuçları Tablo 6'da gösterilmiştir. Yapılan analiz sonucu Buna göre; değişkenler arasında bir eşbütünleşim ilişkisinin olduğu tespit edilmiştir.

\section{VAR ANALIZI}

VAR sistemi, gecikme derecesi 12

SEK (OLS) tahminleri, gözlemler 2008:01-2017:12 ( $\mathrm{T}=120)$

Log-olabilirlik $=-308,64241$

kovaryans dizey belirleyeni $=0,034403705$

$\mathrm{AIC}=6,9940$

$\mathrm{BIC}=9,5725$

$\mathrm{HQC}=8,0412$

Portmanto sinamasi: $\mathrm{LB}(30)=239,85, \mathrm{sd}=162[0,0001]$

Tablo 7. VAR Analiz Sonuçları

Denklem 1: sd_1_EMP

\begin{tabular}{|l|c|c|c|c|l|}
\hline & Katsayl & Ölç. Hata & $t$-oranı & $p$-değeri & Anlamll1ı \\
\hline Const & 0,216701 & 0,0919148 & 2,358 & 0,0207 & - \\
\hline sd_1_EXP_1 & 0,0278150 & 0,113613 & 0,2448 & 0,8072 & - \\
\hline sd_1_EXP_2 & 0,00712858 & 0,130144 & 0,05477 & 0,9564 & - \\
\hline sd_1_EXP_3 & 0,228426 & 0,134185 & 1,702 & 0,0924 & $(\% 90$ Güven) (\%10 Hata) \\
\hline sd_1_EXP_4 & $-0,189664$ & 0,131522 & $-1,442$ & 0,1530 & - \\
\hline sd_1_EXP_5 & $-0,0774879$ & 0,133831 & $-0,5790$ & 0,5642 & - \\
\hline sd_1_EXP_6 & 0,161855 & 0,136206 & 1,188 & 0,2381 & - \\
\hline sd_1_EXP_7 & $-0,00785406$ & 0,135651 & $-0,05790$ & 0,9540 & - \\
\hline sd_1_EXP_8 & $-0,102880$ & 0,139004 & $-0,7401$ & 0,4613 & - \\
\hline sd_1_EXP_9 & $-0,186761$ & 0,143686 & $-1,300$ & 0,1973 & - \\
\hline $\begin{array}{l}\text { sd_1_EXP_1 } \\
0\end{array}$ & $-0,116309$ & 0,139871 & $-0,8315$ & 0,4081 & - \\
\hline sd_1_EXP_1 & 0,0858998 & 0,130379 & 0,6588 & 0,5118 & - \\
\hline sd_1_EXP_1 & 0,147165 & 0,105598 & 1,394 & 0,1671 & - \\
\hline 2 & & 0,163532 & 1,075 & 0,2855 & - \\
\hline sd_1_IMP_1 & 0,175789 & & & & \\
\hline
\end{tabular}




\begin{tabular}{|c|c|c|c|c|c|}
\hline sd_1_IMP_2 & 0,00331530 & 0,165640 & 0,02002 & 0,9841 & - \\
\hline sd_1_IMP_3 & $-0,126514$ & 0,173262 & $-0,7302$ & 0,4673 & - \\
\hline sd_1_IMP_4 & $-0,115763$ & 0,176457 & $-0,6560$ & 0,5136 & - \\
\hline sd_1_IMP_5 & $-0,185267$ & 0,170189 & $-1,089$ & 0,2795 & - \\
\hline sd_1_IMP_6 & 0,149019 & 0,164979 & 0,9033 & 0,3690 & \\
\hline sd_1_IMP_7 & 0,112588 & 0,163242 & 0,6897 & 0,4923 & - \\
\hline sd_1_IMP_8 & 0,342998 & 0,158129 & 2,169 & 0,0329 & $(\% 95$ Güven) (\%5 Hata) \\
\hline sd_1_IMP_9 & $-0,182352$ & 0,158649 & $-1,149$ & 0,2537 & - \\
\hline sd_1_IMP_10 & 0,114255 & 0,173157 & 0,6598 & 0,5112 & - \\
\hline sd_1_IMP_11 & 0,0287848 & 0,165413 & 0,1740 & 0,8623 & - \\
\hline sd_1_IMP_12 & $-0,177225$ & 0,160441 & $-1,105$ & 0,2725 & - \\
\hline sd_1_EMP_1 & 0,0173396 & 0,0986032 & 0,1759 & 0,8608 & - \\
\hline sd_1_EMP_2 & 0,0875513 & 0,113970 & 0,7682 & 0,4446 & - \\
\hline sd_1_EMP_3 & $-0,0730246$ & 0,112957 & $-0,6465$ & 0,5198 & - \\
\hline sd_1_EMP_4 & 0,0441103 & 0,107110 & 0,4118 & 0,6815 & - \\
\hline sd_1_EMP_5 & 0,163271 & 0,0982128 & 1,662 & 0,1002 & - \\
\hline sd_1_EMP_6 & $-0,0193628$ & 0,0999872 & $-0,1937$ & 0,8469 & - \\
\hline sd_1_EMP_7 & 0,00800944 & 0,101319 & 0,07905 & 0,9372 & - \\
\hline sd_1_EMP_8 & 0,118308 & 0,0983972 & 1,202 & 0,2326 & - \\
\hline sd_1_EMP_9 & 0,00372254 & 0,0959657 & 0,03879 & 0,9692 & - \\
\hline \begin{tabular}{|l|} 
sd_1_EMP_1 \\
0
\end{tabular} & 0,0639544 & 0,0931083 & 0,6869 & 0,4941 & - \\
\hline $\begin{array}{l}\text { sd_1_EMP_1 } \\
1\end{array}$ & 0,0673225 & 0,0930067 & 0,7238 & 0,4712 & - \\
\hline \begin{tabular}{|l|} 
sd_1_EMP_1 \\
2
\end{tabular} & $-0,282118$ & 0,0875295 & $-3,223$ & 0,0018 & (\%99 Güven) (\%1 Hata) \\
\hline
\end{tabular}

\begin{tabular}{|l|r|l|r|}
\hline Bağımlı değişken ort & 0,285809 & Bağımlı değişken ö.s. & 1,011568 \\
\hline Kalıntı kareleri top & 53,91329 & Bağlanım ö.h. & 0,805951 \\
\hline R-kare & 0,557250 & Ayarlamalı R-kare & 0,365214 \\
\hline F(36, 83) & 2,901795 & P-değeri(F) & 0,000034 \\
\hline Ro & 0,084627 & Durbin-Watson & 1,815617 \\
\hline
\end{tabular}

Sifır sınırlama için F-sınamaları:

sd_1_EXP tüm gecikmeleri $\mathrm{F}(12,83)=1,7363[0,0735]$

sd_1_IMP tüm gecikmeleri $\mathrm{F}(12,83)=1,0734[0,3929]$

sd__EMP tüm gecikmeleri $\mathrm{F}(12,83)=1,5405[0,1263]$

Tüm değişkenler, gecikme $12 \mathrm{~F}(3,83)=5,3929$ [0,0019]

Sistem bütünü için

Sıfir önsavı: En uzun gecikme $=11$

Almaşı önsav: En uzun gecikme $=12$

Olabilirlik oranı sinamass: Ki-kare(9) $=37,9564[0,0000]$

Yapılan VAR analiz sonucu Tablo 7'de gösterilmiştir. Analiz sonucuna göre; \% 10 hata payı ile (\%90 güvenle), EMP ile EXP arasında kısa dönemde pozitif 
yönlü bir ilişki olduğu, ancak uzun dönemde ise; iki değişken arasında herhangi bir ilişkinin olmadığ tespit edilmiştir. Yine analiz sonucuna göre; \% 5 hata payı ile (\%95 güvenle) EMP ile IMP arasında kısa dönemde pozitif yönlü bir ilişki olduğu, ancak uzun dönemde ise; iki değişken arasında herhangi bir ilişkinin olmadığ ortaya çıkmıştır. 2006 ile 2017 yılları arasında aylık verilere dayanılarak yapılan bu analiz sonucunda, ihracat ile istihdam arasında kısa dönemde ilişki olduğu anacak uzun dönemde ihracatın istihdamı etkilemediği sonucuna ulaşılmıştır. Ayrıca analizde, ithalat ile istihdam arasında kısa dönemde bir ilişkinin varlı̆̆ tespit edilirken, ancak uzun dönemde iki değişken arasında herhangi bir ilişkisinin olmadığı tespit edilmiştir.

\section{ETKİ -TEPKİ ANALIZI}

Etki tepki analizi ile makroekonomik verilerin politika aracı olarak kullanılabilirliği test edilmektedir. Aynı zamanda bu analizi ile makroekonomik değişkenlerde meydana gelen bir standart sapmalık şoka diğer değişkenlerin vermiş olduğu tepki ölçülmüş olur. Bu çerçevede modelde yer alan değişkenlerin etki tepki analizi sonuçları aşağıdaki Şekil 1'de gösterilmiştir.

Şekil 1.Etki-Tepki Fonksiyonu

sd_I_IMP -> sd_I_IMP

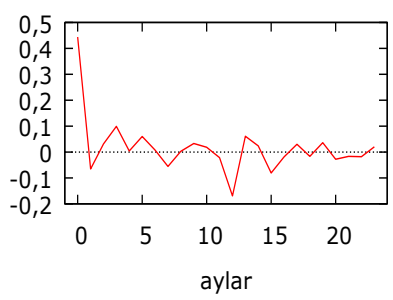

sd_I_IMP -> sd_I_EMP

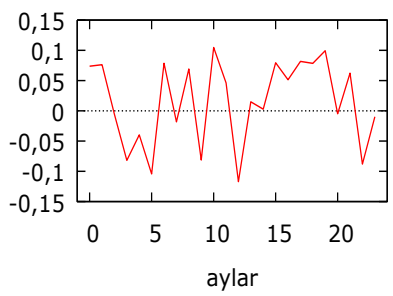

Sd_I_IMP -> sd_I_EXP

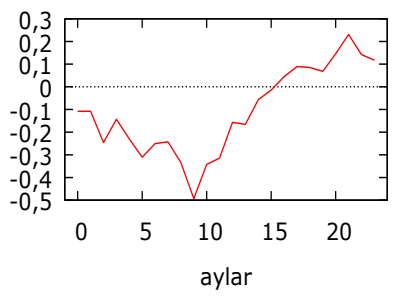

Sd_I_EMP -> sd_I_IMP

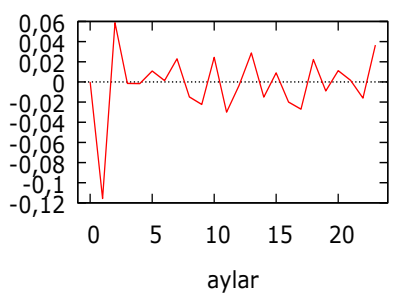

sd_I_EMP -> sd_I_EMP

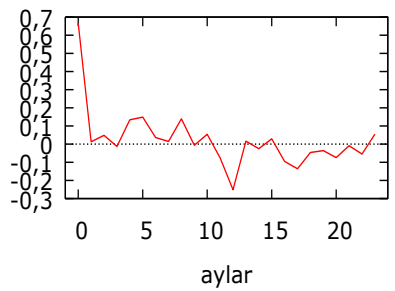

sd_I_EMP -> sd_I_EXP

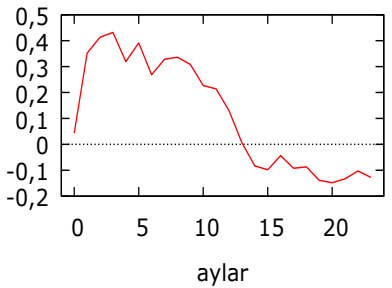

sd_I_EXP -> sd_I_IMP

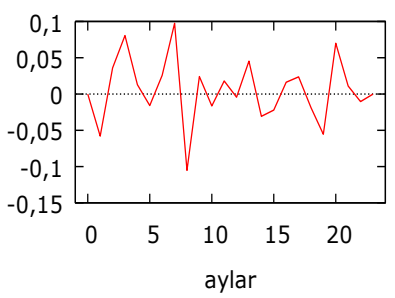

sd_I_EXP -> sd_I_EMP

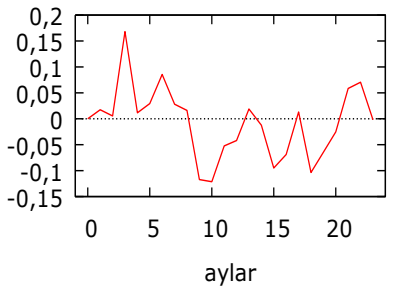

sd_I_EXP -> sd_I_EXP

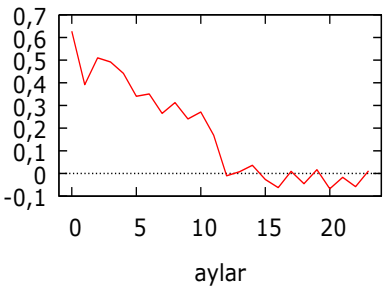


Şekil 1'de modelde yer alan değişkenlerin ayrı ayrı bağımlı değişken olmaları durumundaki bir standart sapmalık şoka vermiş oldukları tepkiler yer almaktadır. Buna göre modelde yer alan ihracat, istihdamı on beşinci dönemden sonra negatif yönlü etkilemiştir. İthalat ise belli dönemler arasında negatif ve pozitif yönlü olarak istihdamı etkilemiş̧tir.

\section{VARYANS AYRISSTIRMASI}

Tablo 8'de EMP için varyans ayrıştırması sonuçları yer almaktadır. Dönemler itibariyle EMP'yi; IMP ve EXP'nin açıklama gücü test edilmiştir. Buna göre; dönemler itibari ile EXP ve IMP'deki değişim EMP'yi etkileme gücüne sahip olduğu görülmektedir.

Tablo 8. sd_1_EMP İçin Varyans Ayrıştırması

\begin{tabular}{|c|c|c|c|c|}
\hline Dönem & ölç. hata & sd_1_IMP & sd_1_EMP & sd_1_EXP \\
\hline 1 & 0,670282 & 1,2102 & 98,7898 & 0,0000 \\
\hline 2 & 0,674956 & 2,4712 & 97,4620 & 0,0668 \\
\hline 3 & 0,676731 & 2,4661 & 97,4609 & 0,0730 \\
\hline 4 & 0,702191 & 3,6527 & 90,5549 & 5,7924 \\
\hline 5 & 0,716088 & 3,8205 & 90,5835 & 5,5959 \\
\hline 6 & 0,739391 & 5,5747 & 89,0196 & 5,4056 \\
\hline 7 & 0,749345 & 6,5282 & 86,9076 & 6,5642 \\
\hline 8 & 0,750239 & 6,5722 & 86,7388 & 6,6890 \\
\hline 9 & 0,76637 & 7,1132 & 86,4323 & 6,4546 \\
\hline 10 & 0,77956 & 7,9639 & 83,5391 & 8,4970 \\
\hline 11 & 0,797713 & 9,3297 & 80,2411 & 10,4293 \\
\hline 12 & 0,80437 & 9,5047 & 79,8140 & 10,6813 \\
\hline
\end{tabular}

İstihdam değişkeninin varyansındaki değişmeleri açıklamada etkili olan birinci önemli değişken ihracat olmaktadır. İkinci ise ithalat olmaktadır. On ikinci dönem sonu itibarıyla istihdamda meydana gelen değişmenin \% 79'ü kendinden, \% 10'u ihracattan, \% 9,5'i ithalattan kaynaklanmaktadır.

\section{BİRIM ÇEMBERE GÖRE VAR TERS KÖKLERI}

Modelde yer alan değişkenler için birim çembere göre VAR ters kökleri analizi aşağıda yapılmıştır.

Şekil 2. VAR Ters Kökleri Birim Çembere Göre

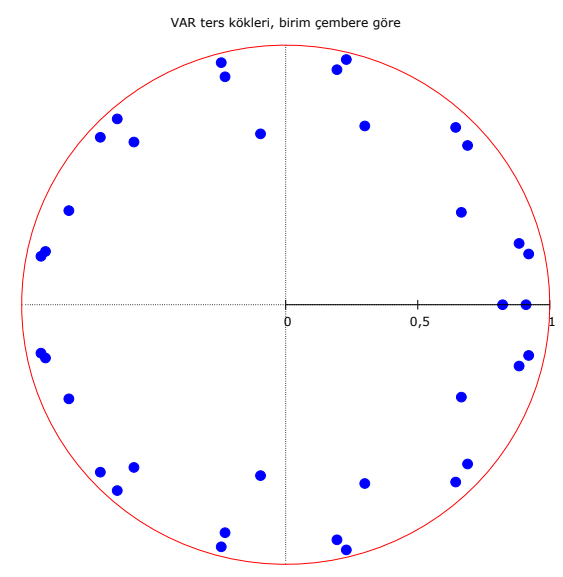


Şekil 2'de VAR ters köklerinin birim çemberin içinde yer alması ve çemberin dışında bulunmamasından dolayı oluşturulan VAR modeli istikrarlı bir yap1 gösterir.

\section{SONUÇ}

Son dönemlerde ülkemizde uygulanan işsizlikle mücadele politikalarında önemli gelişmeler sağlanmıştır. Buna bağlı olarak işsizlikle mücadelede uygulanan istihdam politikalarında hem çeşitlilik açısından hem de katılım açısından artışlar olmuştur. Uygulanan istihdam politikalarını iki ana başlık altında topladığımızda karşımıza aktif istihdam politikaları ve pasif istihdam politikaları çıkmaktadır. Aktif istihdam politikalarının temel amacı işsizlere belli eğitim programları düzenleyerek onların daha kolay iş bulmalarına yardımcı olmak iken, pasif istihdam politikalarının amacı ise; çalışan işgücünün belli bir süre işsiz kalması sonucu ortaya çıkacak olan ekonomik ve sosyal sorunları aşması için işgücüne katkı sağlamaktır.

Yapılan bu çalışmada Karabük ili için 2006 ile 2017 yılları arasındaki dış ticaretteki gelişmelerin istihdam üzerindeki etkisi aylık verilere dayanılarak analiz edilmiştir. Bu amaçla yapılan bu çalışmada ilk olarak dış ticaret ve istihdamla ilgili teorik bilgiler verilmiş, sonra Karabük ilinin işgücü piyasasının son yıllardaki görünümü ayrıntılı bir şekilde ele alınıp incelenmiş, ilerleyen bölümlerde ise ilde dış ticaretteki gelişmeler analiz edilerek istihdamdaki yeri araştırılmıştır.

Genel olarak değerlendirildiğinde Karabük ilinde yıllar itibariyle ortaya çıkan işsizlik oranlarının Türkiye ortalamasına yakın olduğu görülmektedir. İşsizlik rakamlarında meydana gelen büyümeye rağmen istihdamda artış sağlanmış, ancak bu artış işsizlik rakamlarındaki artış kadar yüksek olmamıştır. Dolayısıyla işsizlik Karabük ilinin önemli bir sorunu olarak gündemdeki yerini hala korumaktadır.

Modelde yer alan değişkenlerin 2006 ve 2017 döneminde Karabük ili için almış olduğu değerler aşağıdaki gibi gerçekleşmiştir.

- 2006 yılında işgücü 5082, kayıtlı işsiz 4835 ve işe yerleştirme 388 kişi olarak gerçekleşmiştir.

- 2017 yılında kayıtlı işgücü 19079, kayıtlı işsiz 9280 ve işe yerleştirme 9799 kişi olarak gerçekleşmiştir.

- 2006 ile 2017 yılları arasında kayıtlı işgücündeki artış, kayıtlı işe yerleştirmelerden daha hızlı oranda artış göstermiştir.

- Diş ticaret hacmi 2006 yılında 203.276.000 ABD doları iken, 2017 yılında 1.047.323.000 ABD dolarına yükselmiştir. Dış ticaret hacminde önemli bir artışın olduğu görülmektedir.

- 2006 y1lında 13.915.000 ABD dolar1 ihracat, 89.361.000 ABD doları ithalat gerçekleşmiştir.

- 2017 yilında 326.129.000 ABD dolar1 ihracat, 721.194.000 ABD doları ithalat gerçekleşmiştir.

- Dış ticaret açığı; 2006 yılında 175.447.000 ABD doları iken, 2017 yılında 395.066.000 ABD dolarına yükselmiştir. 
Karabük ili için 2006 ile 2017 yıllarının aylık verilerini kapsayan, EXP, IMP ve EMP değişkenlerinden oluşturulan modelin VAR analizi sonuçları şu şekilde gerçekleşmiştir.

- $\quad \% 10$ hata payı ile (\%90 güvenle), EMP ile EXP arasında kısa dönemde pozitif yönlü bir ilişki olduğu, ancak uzun dönemde ise; iki değiş̧ken arasında herhangi bir ilişkinin olmadığ 1 tespit edilmiştir.

- \% 5 hata payı ile (\%95 güvenle) EMP ile IMP arasında kisa dönemde pozitif yönlü bir ilişki olduğu, ancak uzun dönemde ise; iki değişken arasında herhangi bir ilişkinin olmadığı ortaya çıkmıştır.

Sonuç olarak; Karabük ili için 2006-2017 döneminde aylık verilere göre yapılan analizde, sonucunda, ihracat ile istihdam arasında kısa dönemde ilişki olduğu ancak uzun dönemde ihracatın istihdamı etkilemediği sonucuna ulaşılmıştır. Ayrıca analizde, ithalat ile istihdam arasında kısa dönemde pozitif ilişkinin varlığı ortaya çıkarken, ancak uzun dönemde iki değişken arasında herhangi bir ilişkisinin olmadığı tespit edilmiştir.

Bu çalışmada elde edilen sonucun Türkiye için daha önce yapılan dış ticaret ve istihdam arasındaki ilişkileri inceleyen çalışmaların sonuçları ile benzerlik gösterdiği görülmektedir. Burada şu noktanın da belirtilmesi gerekir. Daha önce literatür de bu konu ile ilgili yapılan çalışmalar genelde bir ülkeyi ya da bir ülke grubunu kapsamaktadır. Yapılan bu çalışma ise sadece bir ili (Karabük) kapsayan çalışma olduğu için diğer çalışmalardan farklılık göstermektedir.

\section{KAYNAKLAR}

Akkuş, G., E., (2014), “ Türk İmalat Sanayiinde Dış Ticaret ve Verimliliğin İstihdam Üzerindeki Etkileri”, İstanbul Üniversitesi, Iktisat Fakültesi Mecmuası, C: 64, 2014/2, s.1-44.

Biçerli,M., K., (2004), İşsizlikle Mücadelede Aktif İstihdam Politikaları, Anadolu Üniversitesi Yayınları No:1563, Eskişehir.

Cütcü, İ., ve Cenger, H., (2017), “Türkiye' de Dış ticaret ve işsizlik Arasındaki İlişki: Yapısal Kırılmalı Zaman Serisi Analizi”, III. Uluslararası Girişimcilik, İstihdam ve Kariyer Kongresi, 12-15 Ekim 2017, Muğla.

Feenstra, R., Ma, H. ve Xu, Y., (2017), “Us Export and Employment”, Nber Working Paper Series (NBER), Working Paper 24056, Working Paper 24056, http://www.nber.org/papers/w24056(e.t.08.05.2018).

Gaston, N., (1998), "The Impact Of Internationaltrade And Protection On Australian Manufacturıng Employment”, Australıan Economic Papers, 1998 June, Volume 37, Issue 2, PP-119-136.

Gökmen, H., (2007), “Avrupa Sosyal Devlet Anlayışında İstihdam Ve Türkiye'de Genç İşsizlik Sorunu”, Uzmanlık Tezi, T.C. Çalışma Ve Sosyal Güvenlik Bakanlığı Türkiye İş Kurumu Genel Müdürlüğ̈̈, Ankara.

Gül, E. ve Kamacı A., (012), "Dış Ticaretin İstihdam Üzerindeki Etkileri: Bir Panel Veri Analizi”, Anadolu Üniversitesi Sosyal Bilimler Dergisi, Cilt/Vol.: 12 - Say1/No: 4, s. 23-32.

Ha, H.,.V., ve Tran, T., Q., (2017), "International Trade and Employment: A Q Quantile Regression Approach", Journal of Economic Integration, Vol.32 No.3, September 2017, pp: 531-557.

Karaçor, Z., ve SARAÇ, T., B., (2011), "Dış Ticaret ile Sanayi Sektörü İstihdam Oranı Arasındaki Kısa ve Uzun Dönem İlişkisi: Türkiye Örneği (1963-2009)”, Celal Bayar Üniversitesi İ.I.B.F., Yönetim veEkonomi, Cilt:18, Say1:2, s.181-194. 
Kızılırmak, A., B., (2012), "Türkiye Özel İmalat Sanayinde Dış Ticaretin İstihdam Üzerindeki Etkisi”, Türkiye Ekonomi Kurumu, Tartışma Metni, 2012/76.

Korkmaz, A. ve Mahiroğulları A.,(2007), Emek Piyasası Politikaları, 2. Baskı, Ekin Yayınevi, Bursa. Köklü, Aziz, Makro İktisat, 2. Baskı, Ankara, S Yayınevi, 1987.

Krueger, A., 0.,(1980), "Protectionıst Pressures, Imports, And Employment In The United States", NBER, Working Paper No. 1461,(www.nber.org e.t:10.05.2018)

Ören, Kenan, Sosyal Politika, Pelikan Yayınları, Ankara, 2011.

Özgen, B., F., ve Güloğlu B., (2004)., "Türkiye’de İç Borçların İktisadi Etkilerinin VAR Tekniğiyle Analizi”, ODTÜ Gelişme Dergisi, Cilt: 31 Sayı: 4, ss. 93-114.

Polat, Ö. ve Uslu, E.E., (2010), "Türkiye İmalat Sanayinde Dış Ticaretin İstihdam Üzerindeki Etkisi”, Gaziantep Üniversitesi Sosyal Bilimler Dergisi, Sayı: 3, s. 489-504.

Polat, Ö., Uslu E., E. ve Aydemir, C., (2011), "İmalat Sanayinde Dış Ticaret ve İstihdamın Panel Veri Analizi”, Business and Economics Research Journal, Volume:2, Number:3, pp. 161171.

Raj, R., ve Sasidharan, S., (2015), “Impact of Foreign Trade on Employment and Wages in Indian Manufacturing”, South Asia Economic Journal, 16(2), p:209-232.( http://journals.sagepub.com/doi/pdf/10.1177/1391561415598457 e.t. :05.05.2018)

Sen, K., (2008), International Trade and Manufacturing Employment Outcomes in India, United Nations University, Unı-Wider, Research Paper No. 2008/87, pp.1-24.

Seyyar, A., Sosyal Siyaset Terimleri Ansiklopedik Sözlük, 2. Baskı, Sakarya, Sakarya Yayıncılık, 2008.

Tuhin, R., (2015), "Impact of international trade on employment: Evidence from Australian manufacturing industries", https://www.industry.gov.au/data-and-publications/staffresearch-papers/impact-of-international-trade-on-employment-evidence-from-australianmanufacturing-industries,(erişim: 10.10.018).

Türkbal, A., İktisada Giriş, Aktif Kitapevi, İstanbul, 2005.

Xiangquan, Z., v.d., (2011), "Real Exchange Rate, Foreign Trade and Employment: Evidence from China”, IZA Discussion Paper No. 5931, August 2011, pp:1-25.

Yalman, İ., N., (2012), “Türkiye'de Dış Ticaretteki Serbestleşmenin İşü̈cü Piyasaları Üzerindeki Etkileri”, Eskişehir Osmangazi Üniversitesi İ̈BF Dergisi, Ekim 2012, 7(2), s. 49-65.

Zaim, S., (1997), Çalışma Ekonomisi, 10. Baskı, Filiz Kitapevi, İstanbul.

İSKUR, http://www.iskur.gov.tr/tr-tr/kurumsalbilgi/istatistikler.aspx\#dltop.

İ̧̧KUR, Karabük İşü̈cü Piyasası Araştırma Raporu-2015.

İŞKUR, Karabük İşgücü Piyasası Araştırma Raporu-2014.

Türkiye İstatistik Kurumu (TÜIK), www.tuik.gov.tr

Türkiye Cumhuriyet Merkez Bankası (TCMB), www.tcmb.gov.tr.

Türkiye İhracatçılar Meclisi (TIM), www.tim.org.tr

\section{SUMMARY}

Employment and unemployment are two different but complementary integral parts of the same truth. Employment constitutes the target to be achieved as a result of the policies implemented and unemployment is the desired party to be avoided. Accordingly, the importance of policies for increasing unemployment and decreasing unemployment is increasing. Analyzing the impact of foreign trade on employment in our country, which is struggling with unemployment, is a necessity. For this reason, various studies have been conducted examining foreign trade and employment.

In this study, firstly the relationship between foreign trade and employment is taken as theoretically. In the following sections, the appearance of the labor market between 2006 and 2017 and the developments in foreign trade have been discussed. In later chapters, the relationship between an econometric modeling and 
foreign trade and employment variables was tested using the VAR model. Study; In 2006 and 2017, the effect of the developments in foreign trade in Karabük on employment was examined with monthly data and the relationship between export and import and employment was determined.

As a result; In the analysis carried out according to the monthly data in the period of 2006-2017 for Karabük province, it is concluded that there is a short-term relationship between exports and employment but that exports do not affect employment in the long term. In the analysis, there was a positive relationship between import and employment in the short term, but it was found that there was no relationship between the two variables in the long run.

Previous studies on this subject in the literature include a country or a country group. As this study is only covering one province (Karabuk), it differs from other studies. 